\title{
New opportunities for experiments in fluvial geomorphology: the flume PTETHYS
}

\author{
Ervin PIRKHOFFER ${ }^{1}$, Áкоs HALMAI ${ }^{1}$, Szabolcs CZIGÁNY ${ }^{1}$, Titusz BUGYA ${ }^{1}$, \\ ANDOR RÁBAY ${ }^{1}$, TAMÁs BÖTKÖS ${ }^{1}$, GÁBOr NAGY ${ }^{1}$, BETTINA BALASSA ${ }^{1}$, \\ ILDIKÓ JANCSKÁRNÉ ANWEILER ${ }^{2}$ and DÉNES LÓCZY ${ }^{1}$
}

\begin{abstract}
In recent decades both physical modelling and computer simulation of fluvial processes has undergone rapid progress. The paper summarizes the achievements of both international and Hungarian laboratory experiments in fluvial geomorphology. Then, the new automatically governed flume facility, called PTETHYS (Project for Tectonical and Hydrological Simulations) recently set up at the Faculty of Natural Sciences, University of Pécs, is presented. Finally, some of the new opportunities it offers for research in fluvial geomorphology are briefly demonstrated: the identification of geomorphological thresholds; modelling the generation of (flash) floods and its application for the reconstruction of the architectural elements and geomorphic evolution of floodplains. Some important channel parameters can be quantitatively investigated: channel cross-section change, amount of bedload influencing braiding, current velocity distribution etc. The novelty of the facility is the easy adjustment of channel slope and continuous experimenting (no need for interruption as in the case of laserscanned experiments). The scaling necessary for quantitative analyses is also tackled.
\end{abstract}

Keywords: physical modelling, flume, channel patterns, flood generation, floodplain rehabilitation, scaling

\section{Introduction}

In recent decades monitoring has been launched in many instrumented catchments all over the world and numerous computer models have been elaborated for the explanation of some of the "eternal" questions of fluvial geomorphology. At the same time, the weaknesses of the first (a labour and

\footnotetext{
${ }^{1}$ Institute of Geography, University of Pécs, H-7624 Pécs, Ifjúság útja 6.

E-mail: pirkhoff@gamma.ttk.pte.hu

${ }^{2}$ Pollack Mihály Faculty of Engeneering and Information Technology, University of Pécs, H-7624 Pécs, Boszorkány u. 2. E-mail: jancskarne.ildiko@pmmik.pte.hu
} 
time-consuming activity involving high expenses) and the second approach (e.g. magnification of errors springing from incorrect parametrisation or limited applicability to real-life situations) have also been recognized.

Observing the scaling rules, the small-scale physical models, long established in water engineering, seem to be capable to bridge the gap between the two approaches. If the results of experimentations could be quantified, physical modelling may also be helpful for the theoretical foundation of various water management tasks (including dam constructions, designing flood control alert and warning or river rehabilitation).

The aim of the project is to apply quantitative methods for the modelling of braided (and in the future meandering) channel evolution. Hopefully, the results can be used in designing river restoration, too. The experiment also helps students to combine their knowledge in laboratory studies, experimental geomorphology and remote sensing.

\section{Previous flume experiments}

Reaching back to the end of the $19^{\text {th }}$ century, physical modelling has a long tradition in water management. It is particularly frequently applied in river channel studies for diverse purposes. The largest hydraulic model ever built in the world replicates the Mississippi River and its major tributaries (the Tennessee, Arkansas and Missouri Rivers) in ca 170 hectares' area near Clinton, Mississippi. Meant to aid flood control planning, it was built by 3,000 German and Italian prisoners of war for the US Army Corps of Engineers in 1944 (FosTER, J.E. 1971). (It still exists now but in a neglected condition.)

In the United States smaller-scale laboratory studies on river channels began by the US Army Corps of Engineers in Vicksburg, Mississippi, in 1929. The first experiments, however, only modelled the origin of a meandering thalweg instead of a meandering channel (a famous example being FrIEDKIN, J.F. 1945). A later recognition that pattern changes occur rather abruptly in rivers in the course of a punctuated evolution and are driven by channel gradient and the mode of sediment transport (Leopold, L.B. and Wolman, M.G. 1957; Schumm, S.A. and Khan, H.R. 1972; Miall, A.D. 1996). These led to experiments where gradient and sediment supply were changed, while water discharge was kept constant, and parameters like channel width/depth ratio, mean current velocity, bedload discharge and concentration, shear and Froude number were recorded (Sснuмm, S.A. 1973). The morphodynamics, particularly the depositional activity of braided rivers have been intensively studied in experiments (e.g. Ashworth, P.J. et al. 1994).

In fluvial geomorphology the second half of the $20^{\text {th }}$ century was a period of identification of important thresholds. Such are the critical channel 
gradient values which separate straight, meandering and braided channel patterns - a major issue in fluvial geomorphology of the 1970s (Sснимм, S.A. and Khan, H.R. 1972; Schumm, S.A. 1973; Brotherton, D.I. 1979).

The importance of bank strength was also recognised in determining channel pattern (KLEINHANS, M.G. 2010), rivers with stronger (often vegetated) banks being narrower and deeper, and alternate bars common in their channel. Although it is widely accepted that bank-erosion rate and floodplain sedimentation, influenced by more complicated factors than just channel flow and sediment transport (FrIedKIN, J.F. 1945; Fraselle, Q. et al. 2010), are extremely difficult to scale (Ashworth, P.J. et al. 2004), it is also noted that even small-scale experiments adequately reproduce spatial patterns and the natural system dynamics (PAOla, C. et al. 2009).

The importance of sediment transport was also recognised internationally (Ferguson, R.I. 1987) and in Hungary, too. In 1951 László KÁDÁr began to set up a flume at the Kossuth Lajos University of Debrecen, Hungary, to study fluvial geomorphological processes and drew attention to the part sediment transport plays in the (trans)formation of channel patterns. On the basis of the visual observations made in the flume, he published papers (KádÁr, L. 1954, $1955,1969)$, where he presented a geomorphologically more consistent picture of meandering than it was usual at the time when the "theory of types of river reaches", borrowed from Germany, prevailed (Sipos, Gr. and KIss, T. 2008).

In Hungarian water engineering model experiments started in 1928, when Sándor Rohringer installed a hydraulic laboratory of $670 \mathrm{~m}^{2}$ area at the Department of Water Construction, Budapest Technical University. The aim of the first experiment was to investigate the hydraulics of the Danube channel at the artificial cut-off of Bogyiszló (Sárköz, South Hungary) (FejÉr, L. 2001). In 1967 the Research Institute for Water Resources Management (VITUKI) established a hydrological model at the village Nick (PAnnonhalmi, M. 2004). A flume of $40 \times 6 \mathrm{~m}$ size supplemented with a glass channel $15 \mathrm{~m}$ long and $0.5 \mathrm{~m}$ wide was built to model a section of the Rába River. The experiments were conducted with the purpose of modelling meander shifts and the impacts of river regulation and served the basis for 48 river regulation proposals. However, the modelling of sediment transport was not satisfactory. After 2007 the facility was not used.

The largest physical model in Hungary served the checking of the rehabilitation plans for the Danube floodplain in the Szigetköz after the construction of the Bös (Gabčíkovo) Barrage and diversion of the main channel in 1992. The upper Szigetköz section of the Danube (from Dunakiliti to Dunaremete) was modelled at 1:500 scale, while the lower (from Dunaremete to Medve) at 1:700 scale in the Ecopark of Dunasziget. The impacts of river regulation are also reconstructed through the use of physical models (see e.g. Kornis-Akantisz, Zs. 1977). 


\section{Flume parameters}

The new flume of the University of Pécs is intended both for educational and research purposes (Photo 1). It was designed by experts of the Department of Physical and Environmental Geography, Institute of Geography, and the Department of Mechanical Engineering, Pollack Mihály Faculty of Engineering and Informatics, University of Pécs, in 2012. The technical documentation, manufacturing and installation was the responsibility of the CsavarKONTROLL 2004 Ltd.

The versatility of the flume is demonstrated by its technical parameters, which are the following:

- size: $4.2 \times 2.5 \mathrm{~m}$;

- maximum fill weight: $2,500 \mathrm{~kg}$ (wet sediment in $150 \mathrm{~mm}$ depth);

- maximum tilting: around longitudinal axis: \pm 7.5 , around transversal axis: +10 ;

- adjustable parts: 6 sections can be moved vertically $\pm 120 \mathrm{~mm}$ at $10-200$ $\mathrm{mm}$ per day speed;

- lateral deformation: possible through the displacement of 4 pushblades to the extent of $100 \mathrm{~mm}$;

- closed equipment, water and sediment can only leave it through the sink.

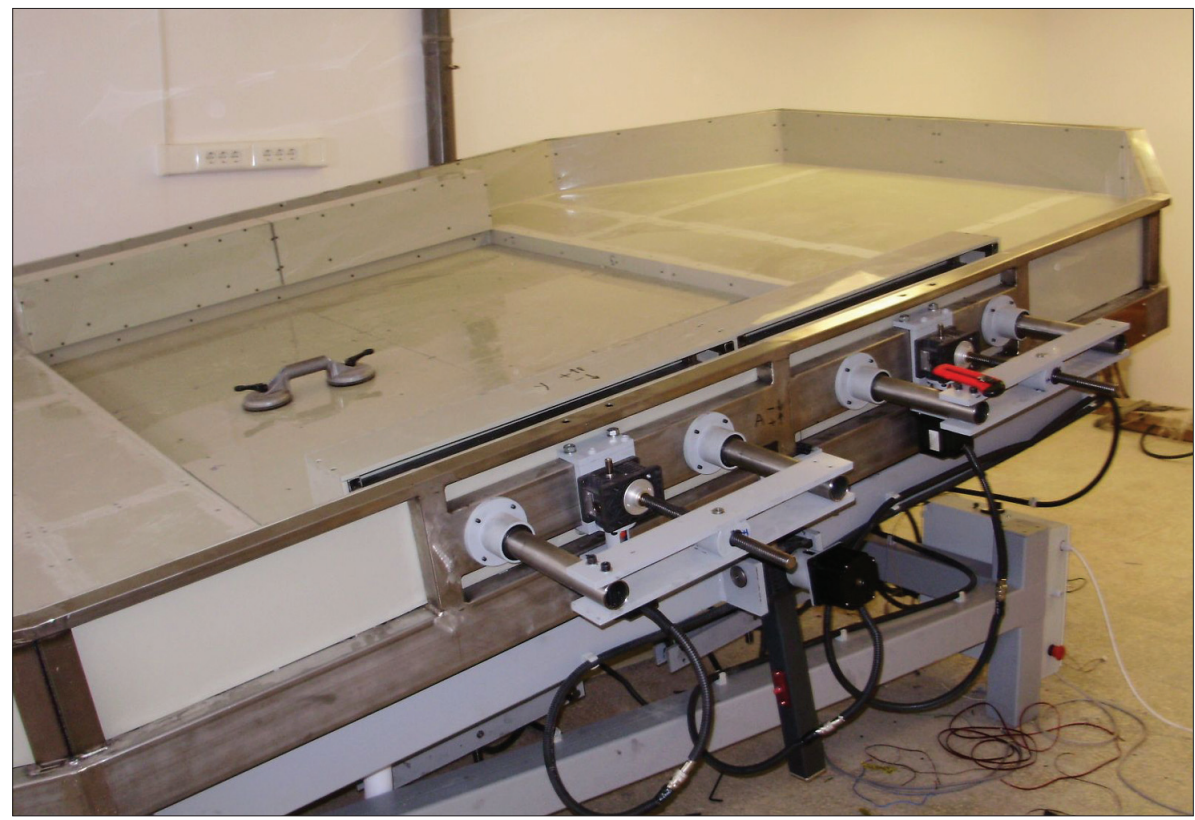

Photo 1. View of the PTETHYS flume before installation 
All motions in the flume are executed by computer-governed electroengines. The speed of movements allows the modelling of both very slow and rather rapid changes. The rate of motions is checked by Leica Disto D3a BT laser meters (automatic feedback through Bluetooth).

Discharge is regulated through a 1-m-high water column, adjusted automatically to the position of the table. Water is recycled by a pump system.

The processes are detected through two devices. On the one hand, detailed picture information is collected and all physical parameters of the processes taking place in the flume are recorded by the use of eight Canon EOS 1100D cameras (Photo 2). The cameras are fixed on a system of cantilevers at $30 \mathrm{~cm}$ distance from each other and at $1.2 \mathrm{~m}$ height above bed. At $18 \mathrm{~mm}$ focal length the overlap between photographs is ca $80 \%$, which allows 3D imaging. The cameras are connected to the PC and governed by a software of author's design.

In addition to the photographic cameras, a VarioScan 3021 ST type thermal camera is also used to establish the actual position of flowing water, the configuration of active channels, current velocity and the horizontal distribution of sediment fill saturation. The observation province of the thermal camera is between 8 and $12 \mu \mathrm{m}$ and its thermal resolution is $\pm 0.03 \mathrm{~K}$.

Since the moisture content of the modelling medium (sediment) of the flume is of utmost importance from the point of view of fluvial processes, the moisture content is recorded at several depths by sensors of Decagon 10HS TDR system and the data are stored by Decagon EM50 data loggers.

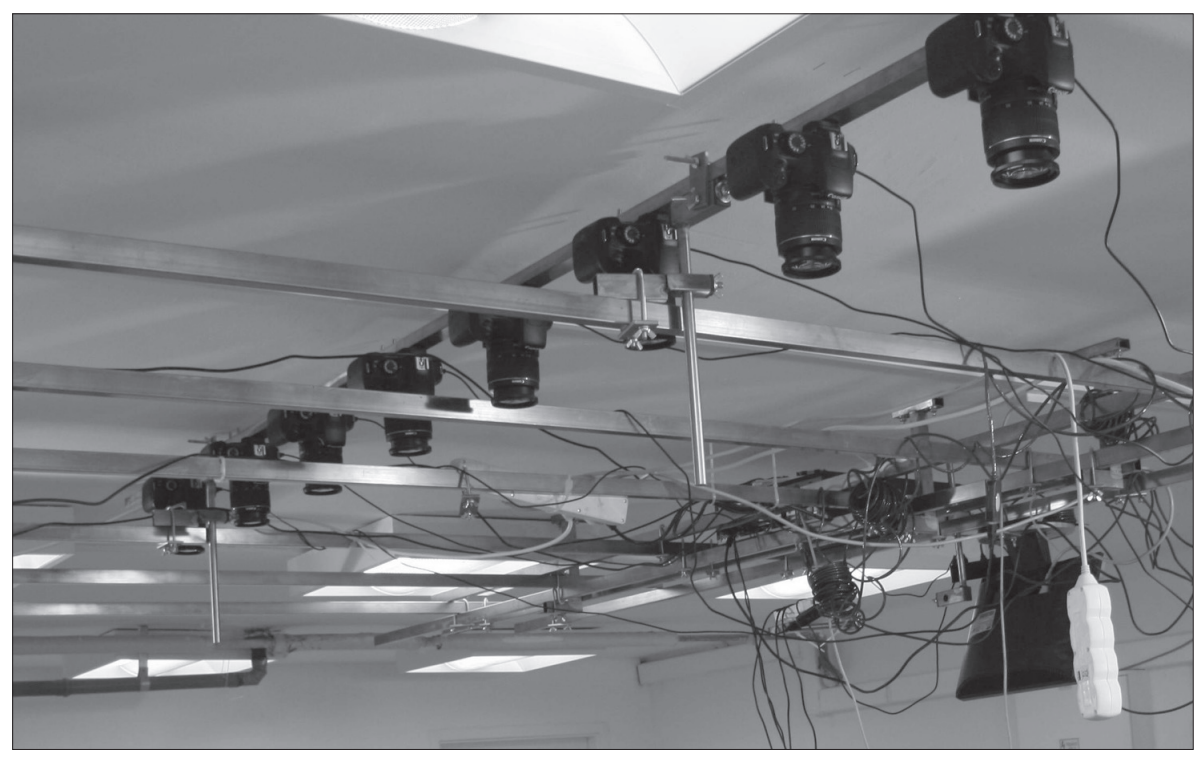

Photo 2. The cameras installed to record geomorphic processes 
The material used for the sediment fill is also carefully designed and manufactured particularly for this purpose. The colours of grains indicate grain size and density: coarse grains (1.0 and $0.8 \mathrm{~mm}$ diameter) are ground basalt and andesite of grey and black colour, while the $0.6 \mathrm{~mm}$ diameter grains are of red marble and those of $0.2 \mathrm{~mm}$ diameter are of beige limestone.

The functions of governing flume position on the one hand and imaging and data logging on the other are shared between different computers. For imaging an Asus P9X79 PRO computer with Intel Core i7-3820 processor and nVidia GTX 660 Ti video card is applied. The operating system and processing is based on two Samsung 250 GB SATA3 2.5" Basic (MZ-7TD250BW) SSDs, while data are stored by Seagate Barracuda 3 TB 64 MB 7,200 rpm SATA3 3.5" (ST3000DM001) HDDs.

Image processing of stereo pairs and the representation of topography is performed by Agisoft StereoScan program. For the interpretation of the DEM and detection of processes ArcGIS 10.2.1 software is available.

\section{Possible applications}

The objective of the first experiment with the new flume was to find out how reliably the development of channel patterns can be modelled. The flume was filled with material of $8 \mathrm{~cm}$ depth and tilted at 5 degrees ( 0.087). Imaging interval (both photographic and thermal) was set to 30 seconds.

Preliminary wetting was applied to reach 40 percent of the saturation moisture content all over the experiment area. In order to trigger and accelerate the process of channel incision a longitudinal groove of ca $2 \mathrm{~cm}$ depth was "burned" into the sediment surface. Previous observations showed that in lack of such an intervention, no collection of runoff into a channel would take place within an acceptable time span.

To identify active channel flow and current velocities, boiling water was conducted in pulses into the flume and its motion was detected by the thermal camera. The resulting channel cross-sections and sediment transport were studied in 3D images.

\section{Braided channel evolution}

Since Sснимm, S.A. and Khan, H.R. (1972) found that channels above 0.016 gradient form a braided pattern, it was expected that such pattern will be the outcome from the first experiment (Figure 1).

In the non-cohesive material increasing discharge led to gradually broadening channels, providing space for more and more bifurcations 


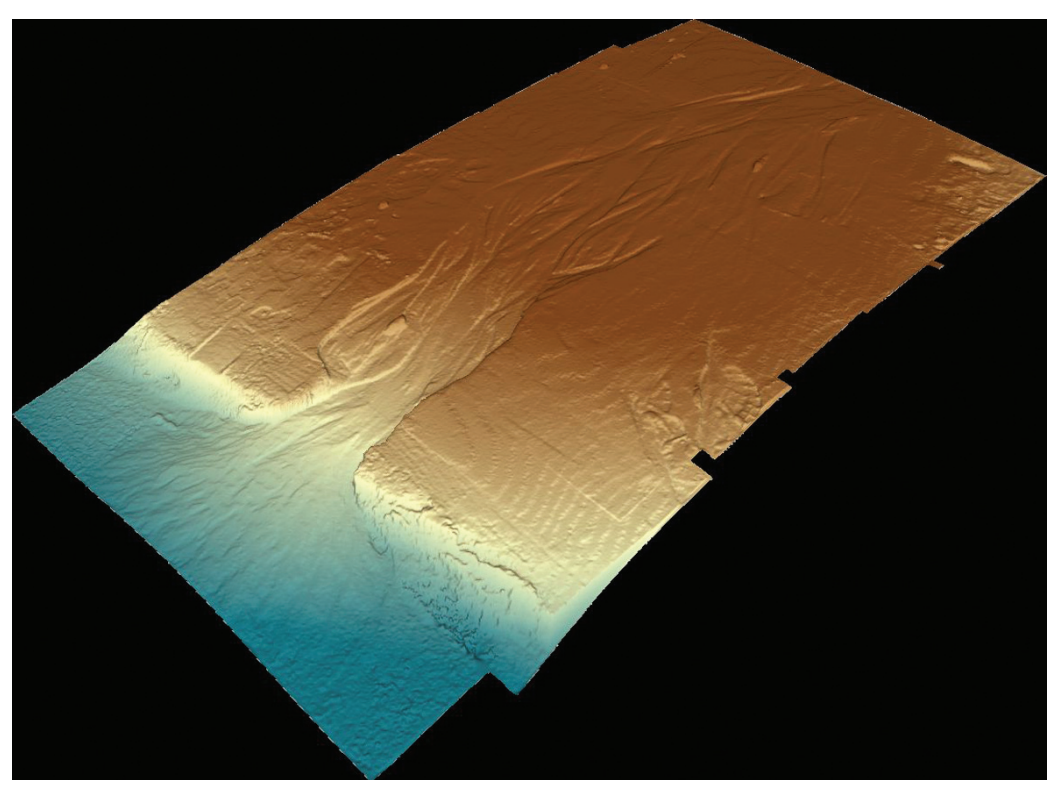

Fig. 1. The braided channel pattern generated in the first experiment

and the building of bars of various types. Thus, all the main morphological requirements for braiding were fulfilled. Since the banks are easily erodible, channel width remarkably fluctuates, but the width/depth ratio remains high throughout. During the experiment the following partial processes could be visually identified:

- channel widening through bank erosion;

- lateral bar accumulation;

- transverse bar accumulation and the resultant diversion of the thalweg;

- occasional reduction in the plan curvature of the thalweg, resulting in channel widening;

- emergence of bifurcations and mid-channel bars at regular distance from each other in broader channel sections;

- alternating cut and fill along the thalweg, which leads to a continuous displacement of braids, a dynamic rearrangement of pattern.

The observed channel evolution corresponds to the observations by BERTOLDI, W. et al. (2001). The braided sections were locally replaced by anastomosing reaches, where the following partial processes were clearly visible:

- with widening channel and lowering water level, some bars rise above the general surface as more stable "islands";

- the distributary channels bordering islands are very shallow just downstream the bifurcation and only convey water at high water stages ("floods"); 


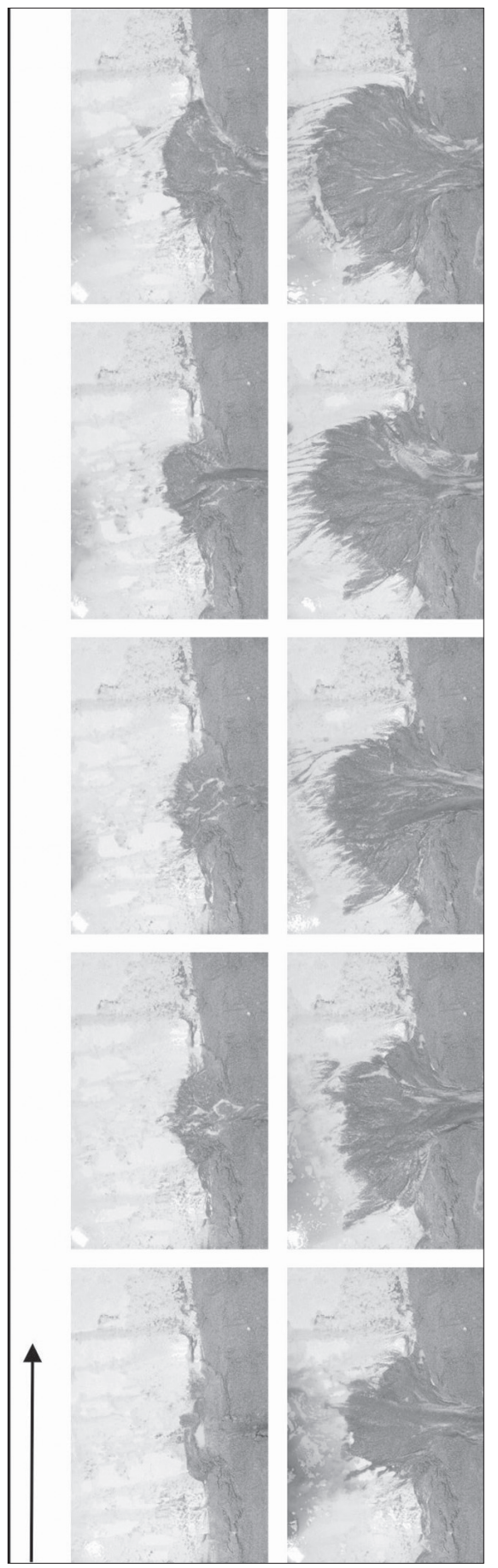

- bifurcations are gradually replaced by avulsions (more permanent displacements of channel) where sediment accumulation is rapid, the distributary channels will acquire a slightly convex longitudinal profile;

- avulsions are concentrated where bank erosion is not particularly efficient since the banks are relatively stable but breach abruptly when reaching a threshold.

Comparing these observations 苋 with some descriptions of field studies (e.g. Miller, J.R. 1991), remarkable resemblances are seen. The development of avulsions is of great practical significance as far as flood hazard is concerned.

Due to the tilting function of the flume, the adjustable channel gradient allows the experimental establishment of further thresholds, e.g. between meandering and braided river behaviour (PARKER, G. 1976; РёsрӧкI, Z. et al. 2005). Its significance is underlined by recent papers, where the challenge of physical modelling of meandering river behaviour is pointed out (van Dijk, W.M. et al. 2012).

\section{Delta formation}

Another experiment proves that the equipment is suitable for the modelling of delta formation (Photo 3). Flume observations show that delta accumulation is composed of the following partial processes:

- the surface of the fan is continuously raised by accumulations by the main channel, which is continuously wandering and deposits large amounts of sediment; 
- the main channel is affected by repeated avulsions and shifts to the lowest-lying zone of the delta fan;

- if water discharge increases, vertical accretion also raises the level of inter-channel surfaces.

Similar channelisation, avulsion and backward sedimentation processes on deltas of homogeneous material were found during experiments in the Netherlands (VAN DE LageweG, W. 2013).

\section{Flood modelling}

In addition to in-channel geomorphic processes, overbank erosion and deposition can also be included among the objectives of physical modelling. This presupposes of creating an exact replica of the floodplain surface. The previously applied GIS-based modelling of flood hazard (e.g. CzIGÁnY, Sz. et al. 2011) can be supplemented by flume experiments locating the potential sites of dyke breaches and avulsions as well as the predictable extent of floodplain inundation. If the boundary conditions leading to river flooding are exactly defined during the experiment, first of all, local flood hazard (Lóczy, D. et al. 2009) can be precisely determined. The morphometric indices derived from the experiments are useful for estimating local flood hazard along channelized rivers and designing the necessary flood-control measures.

\section{Floodplain rehabilitation planning}

Through modelling channel migration and the related deposition processes, flume experiments are a potentially useful tool for reconstructing historical floodplain evolution under natural and human-induced conditions. Their advantages over field data are the opportunity to set both initial and boundary conditions and the much faster operation of processes. With appropriate monitoring technology, morphological changes and the resultant architectural elements can be recorded without intervention into the processes.

Channel evolution observations may be the starting point for the reconstruction of long-term floodplain evolution (Pizzuto, J.E. 1987; BATHURST, J.C. et al. 2002; SEllin, R.H.J. et al. 2003; VAn DiJK, W.M. et al. 2013). In the flume the rate of sediment exchange between the main channel and distributaries can be measured and deposition patterns on the floodplain demonstrated. From data on natural floodplain evolution and human-influenced processes in the floodplain, the measures necessary to create conditions under which the ecosystem functions of floodplains are optimally fulfilled (i.e. floodplain rehabilitation) can be derived. 


\section{Similarity scaling}

Until very recently physical models had been treated as analogue systems in comparison to real-world fluvial systems. Thus, the results of the experiments only allowed qualitative analyses of processes and the resultant landforms. Modern technology developed for the documentation of experimentation outcomes (e.g. DEM representation of high spatial resolution and digital photography of high temporal resolution) makes measurements and quantitative assessment possible.

A major problem in the quantitative interpretation of the processes recorded in flume experiments is seen in the spatial and temporal scaling. For scaling a set of rules have been established but not yet convincingly checked (KLEINHANS, M.G. et al. 2010). The complexity of scaling to achieve similarity is addressed by numerous authors (see PAOLA, C. et al. 2009). Hydraulic scaling involves similarity in flow criticality (Froude number), current velocity, turbulence (Reynolds number), surface tension effects and bed roughness, while sediment-transport similarity refers to sediment mobility (Shields number), shear stress, particle size (Reynolds particle number) and suspended sediment (which is again the function of turbulence). We can also mention morphological similarity, i.e. the cumulative effect of width-to-depth ratio, channel bar dimensions and wavelength, transverse bed slope and other morphological parameters. Most of the above scaling factors have a temporal aspect, too, which also has to be considered.

A task of future research is to further develop the scaling rules in order to produce realistic and meaningful morphodynamics and stratigraphy (VAN De LAGEWEG, W. 2013).

Acknowledgements: The project was partially financed from TÁMOP/SROP-4.2.2.C-11/1/ KONV-2012-0005 (Well-being in the Information Society) and by the Hungarian National Scientific Research Fund (OTKA, contract number K 104552).

\section{REFERENCES}

Ashworth, P.J., Best, J.L. and Jones, M. 2004. Relationship between sediment supply and avulsion frequency in braided rivers. Geology 32. 21-24.

Ashworth, P.J., Best, J.L., Leddy, J.O. and Geehan, G.W. 1994. The physical modelling of braided rivers and deposition of fine-grained sediment. In Process Models and Theoretical Geomorphology. Ed. Kirкву, M.J., Chichester, Wiley, Chichester. $115-139$.

Bathurst, J.C., Benson I.A., VAlentine, E.M. and Nalluri, C. 2002. Overbank sediment deposition patterns for straight and meandering flume channels. Earth Surface Processes and Landforms 27. 659-665.

Bertoldi, W., Tubino, M. and Zolezzi, G. 2001. Laboratory measurements on channel bifurcations. Trento, University of Trento, Trento. 10 p. http://www.ing.unit. it/ bertoldiw_Laboratory_measurements_on_channel_bifurcations.pdf 
Brotherton, D.I. 1979. On the origin and characteristics of river channel patterns. Journal of Hydrology 44. 211-230.

Czigány, Sz., Pirkhoffer, E., Nagyváradi, L., Hegedús, P. and Geresdi, I. 2011. Rapid screening of flash-flood-affected watersheds in Hungary. Zeitschrift für Geomorphologie 55. Supplementary Issue 1. 1-13.

Fejér, L. 2001. Vizeink krónikája (Chronicle of our waters). Budapest, Vízügyi Múzeum, Levéltára, Budapest. 307 p. (in Hungarian)

FERGUSON, R.I. 1987. Hydraulic and sedimentary controls of channel pattern. In River channels: environment and process. Ed. Richards, K.S. Oxford, Blackwell, Oxford. 125-158.

Forster, J.E. 1971. History and description of the Mississippi Basin Model. MRM Report 1-6. 115-126.

Fraselle, Q., Bousmar, D. and Zech, Y. 2010. Experimental investigation of sediment deposition on floodplains. In River Flow 2010. Eds. Dittrich, A., Koll, Ka., Aberle, J. and Geisenhainer, P. 8-10 September 2010, Braunschweig, Germany. Bundesanstalt für Wasserbau, Karlsruhe,. 823-830.

FriedKIN, J.F. 1945. A laboratory study of meandering of alluvial streams. Vicksburg, MS., US Army Corps of Engineers Waterways Experiment Station, 40 p.

KÁDÁR, L. 1954. Az eróziós folyamatok dialektikája (Dialectics of erosion processes). Közlemények a Debreceni Kossuth Lajos Tudományegyetem Földrajzi Intézetéből (Papers of the Institute of Geography, Kossuth Lajos University of Debrecen) 18. 1-20. (in Hungarian)

KÁDÁr, L. 1955. Das Problems des Flussmäander. Közlemények a Debreceni Kossuth Lajos Tudományegyetem Földrajzi Intézetéból (Papers of the Institute of Geography, Kossuth Lajos University of Debrecen) 21. 1-24.

KÁDÁr, L. 1969. Specific types of fluvial landforms related to the different manners of load-transport. Acta Geographica Debrecina 8-9. 115-178.

KLeinhans, M.G. 2010. Sorting out river channel patterns. Progress in Physical Geography 34. 287-326.

Kleinhans, M.G., Van Dijk, W.M., Van de Lageweg, W.I., Hoendervoogt, R., Markies, H. and SchuUrman, F. 2010. From nature to lab: scaling self-formed meandering and braided rivers. In River Flow 2010. Eds. Dittrich, A., Koll, Ka., Aberle, J. and Geisenhainer, P. 8-10 September 2010, Braunschweig. Vol. 2. Karlsruhe, Bundesanstalt für Wasserbau, Karlsruhe. 1001-1010.

Kornis A.-NÉ AkAntisz, Zs. 1977. Mozgó medrű folyószabályozási kisminta-kísérletek (Model experiments for river regulation with moveable bed). Hidrológiai Közlöny 12. 546-553. (in Hungarian)

Leopold, L.B. and Wolman, M.G. 1957. River channel patterns: braided, meandering, and straight. US Geological Survey Professional Paper 282-B. Washington, D.C.

Lóczy, D., Kis, E. and Schweitzer, F. 2009. Local flood hazards assessed from channel morphometry along the Tisza River in Hungary. Geomorphology 113. 200-209.

Miall, A.D. 1996. The geology of fluvial deposits: sedimentary facies, basin analysis, and petroleum geology. New York, Springer, $582 \mathrm{p}$.

Miller, J.R. 1991. Development of anastomosing channels in south-central Indiana. Geomorphology 4. 221-229

Pannonhalmi, M. 2004. A nicki kisminta kísérleti telep története, jelenlegi állapota. (History and presend-day state of the hydraulic model at Nick). Presentation at the Annual Meeting of the Hungarian Hydrological Society, Győr, 18 May 2004. (in Hungarian) 
Paola, C., Straub, K.M., Mohrig, D.C. and Reinhardt, L. 2009. The "unreasonable effectiveness" of stratigraphic and geomorphic experiments. Earth-Science Reviews 97. 1-43.

PARker, G. 1976. On the cause and characteristic scales of meandering and braiding in rivers. Journal of Fluid Mechanics 76. (3): 457-480.

Pizzuto, J.E. 1987. Sediment diffusion during overbank flows. Sedimentology 34. 301-317.

Püspöki, Z., Szabó, Sz., Demeter, G., Szalai, K., McIntosh, R.W., Vincze, I., Németh, G. and Kovács, I. 2005. The statistical relationship between unconfined compressive strengths and the frequency distributions of slope gradients: A case study in northern Hungary. Geomorphology 71. (3-4): 424-436.

Sснимм, S.A. 1973. Geomorphic threshold and complex response of drainage systems. In: Fluvial geomorphology. Ed. Morisawa, M. Binghampton Publications in Geomorphology 3. 299-310.

Sснимм, S.A. and KHAN, H.R. 1972. Experimental study of channel patterns. Geological Society of America Bulletin 83. 1755-1770.

SEllin, R.H.J., Bryant, T.B. and Loveless, J.H. 2003. An improved method for roughening floodplains on physical river models. Journal of Hydraulic Research 41. (1): 3-14.

Sipos, Gy. and Kiss, T. 2008. A medermintázatok értelmezése Kádár László kutatásainak fényében (Explanations of channel patterns in the light of László Kádár's investigations). In Geographia generalis et specialis. Eds. Szabó, J. and Demeter, G. Debrecen, Kossuth Egyetemi Kiadó. 49-54. (in Hungarian)

SZITE 2007. Javaslat a Szigetköz-Csallóközi hullámtéri mellékágrendszer többcélú rehabilitációjára (Proposal for the multi-purpose rehabilitation of the Szigetköz-Csallóköz by-channel system in the active floodplain). Szigetközi Természetvédelmi Egyesület (Szigetköz Association for Nature Conservation), 28 p. (in Hungarian) http://www.szite.hu/ hun/duna_rehabilitacio.html

VAN DE LAGEWEG, W. 2013. Morphodynamics and sedimentary architecture of meandering rivers. PhD Thesis. Utrecht, Utrecht University, Faculty of Geosciences, Department of Physical Geography, Utrecht. 159 p. http://about.me/wietsevandelageweg

van DijK, W.M., van De LAgeweG, W.I. and KLeinhans, M.G. 2012. Experimental meandering river with chute cutoffs. Journal of Geophysical Research 117. F03023, doi:10.1029/2011JF002314.

VAN DijK, W.M., van DE LAgEwEG, W. and KLEINHANS, M.G. 2013. Formation of a cohesive floodplain in a dynamic experimental meandering river. Earth Surface Processes and Landforms 38. (13): 1550-1565. 